\title{
Application of Response Surface Methodology (RSM) for Optimization of Anti-Obesity Effect in Fermented Milk by Lactobacillus plantarum Q180
}

\author{
Sun-Young Park, Seong-A Cho, and Sang-Dong Lim* \\ Korea Food Research Institute, Seongnam 463-746, Korea
}

\begin{abstract}
Obesity, a condition in which an abnormally large amount of fat is stored in adipose tissue, causing an increase in body weight, has become a major public health concern worldwide. The purpose of this study was to optimize the process for fermented milk for the production of a functional product with an anti-obesity effect by using Lactobacillus plantarum Q180 isolated from human feces. We used a 3-factor, 3-level central composite design (CCD) combined with the response surface methodology (RSM). Concentration of skim milk powder $\left(\%, \mathrm{X}_{1}\right)$, incubation temperature $\left({ }^{\circ} \mathrm{C}, \mathrm{X}_{2}\right)$, and incubation time $(\mathrm{h}$, $\left.\mathrm{X}_{3}\right)$ were used as the independent factors, whereas $\mathrm{pH}\left(\mathrm{pH}, \mathrm{Y}_{1}\right)$, anti-lipase activity $\left(\%, \mathrm{Y}_{2}\right)$ and anti-adipogenetic activity $\left(\%, \mathrm{Y}_{3}\right)$ were used as the dependent factors. The optimal conditions of fermented milk for the highest anti-lipase and antiadipogenetic activity with $\mathrm{pH} 4.4$ were the $9.5 \%$ of skim milk powder, $37^{\circ} \mathrm{C}$ of incubation temperature, $28 \mathrm{~h}$ of incubation time. In the fermentation condition, the predicted values of $\mathrm{pH}$, anti-lipase activity and anti-adipogenetic activity were 4.47 , 55.55 , and $20.48 \%$, respectively. However, the actual values of $\mathrm{pH}$, anti-lipase activity and anti-adipogenetic activity were $4.50,52.86$, and $19.25 \%$, respectively. These results demonstrate that $9.5 \%$ of skim milk powder and incubation at $37^{\circ} \mathrm{C}$ for $28 \mathrm{~h}$ were the optimum conditions for producing functional fermented milk with an anti-obesity effect.
\end{abstract}

Keywords: Lactobacillus plantarum, optimization, anti-lipase activity, anti-adipogenetic activity

\section{Introduction}

Obesity is becoming increasingly prevalent among adults, adolescents and children and has become a major public health concern worldwide (Yanovski and Yanovski, 2002). Indeed, obesity is closely related with several metabolic syndromes such as hypertension, diabetes, hyperlipidemia, and arteriosclerosis (Tanida et al., 2008). For these reasons, numerous people have an interest in this issue.

Lactic acid bacteria (LAB) possess special physiological activities and are generally regarded as safe (GRAS). LAB have been widely used in a number of fermented foods, particularly in the production of dairy and vegetable products with functional and probiotic properties (Karahan et al., 2010; Leroy and Vuyst, 2004). As regards their use as probiotics, LAB are reported to have various beneficial effects on the health of hosts once consumed in adequate amounts. These effects include the modulation

\footnotetext{
*Corresponding author: Sang-Dong Lim, Korea Food Research Institute, Seongnam 463-746, Korea. Tel: +82-31-780-9082, Fax: +82-31-780-9160, E-mail: limsd@kfri.re.kr
}

of immune responses (Salminen et al., 2002), and anticarcinogenic and anti-oxidative activities (Choi et al., 2006). In addition to these effects, certain LAB have been found to be effective in regulating adipose tissue in overweight adults (Kadooka et al., 2010) as well as in a dietinduced obese animal model (Takemura et al., 2010).

Individual LAB has a specific fermentation profile, such as the ability to form functional substances and to produce acid. Thus, taking the profiles of LAB into consideration is a significant factor when it is used as a starter in the production of fermented foods (Komatsuzaki et al., 2005).

The response surface methodology (RSM), which was first described by Box and Wilson (Box and Wilson, 1951), is a collection of statistical and mathematical techniques. It is based on the fit of a polynomial equation to experimental data (Bezerra et al., 2008). Because RSM is an efficient experimental strategy for seeking optimal conditions for a multivariable system, it has been successfully employed in optimizing the culture conditions (Box et al., 1978).

The aim of this study is to optimize the fermentative parameters in order to apply them to functional food products which have an anti-obesity effect. 


\section{Materials and Methods}

\section{Bacterial strains}

A LAB strain having an anti-obesity effect, namely, $L$. plantarum $\mathrm{Q} 180$, was isolated from feces of healthy adults. In our previous study, L. plantarum Q180 was found to have lipase inhibitory activity of $83.61 \pm 2.32 \%$ and to inhibit the adipocyte differentiation of 3T3-L1 cells (14.63 $\pm 1.37 \%$ ) at a concentration of $100 \mu \mathrm{g} / \mathrm{mL}$ (Park et al., 2014). The strain was incubated in Lactobacilli MRS broth (Difco, USA) as the growth medium at $37^{\circ} \mathrm{C}$ for $18 \mathrm{~h}$.

\section{Anti-adipogenetic activity}

\section{Cell line and cell culture}

3T3-L1 cells were cultured as described by Hemati et al. (1997). The 3T3-L1 cells were obtained from the American Type Culture Collection (ATCC, USA) and cultured in Dulbecco's modified Eagle's medium (DMEM; GIBCO, USA) containing a high glucose content supplemented with $10 \%$ bovine calf serum (BCS; GIBCO, USA) and $1 \%$ penicillin/streptomycin (Sigma, USA) at $37^{\circ} \mathrm{C}$ in a humidified $5 \% \mathrm{CO}_{2}$ atmosphere. To induce differentiation, 2-d post-confluent cells $(0 \mathrm{~d})$ were stimulated for $2 \mathrm{~d}$ with an adipocyte differentiation cocktail medium containing 5 mM 3-isobutyl-1-methylxanthine (IBMX; Sigma, USA), $1 \mathrm{mM}$ dexamethasone (Dex; Sigma, USA), and 5 $\mathrm{g} / \mathrm{mL}$ of insulin (Sigma, USA) in DMEM supplemented with $10 \%$ fetal bovine serum (FBS; GIBCO, USA) and $1 \%$ penicillin/streptomycin. On $2 \mathrm{~d}$, the medium was replaced with DMEM containing 10\% FBS, 1\% penicillin/ streptomycin, and $5 \mathrm{~g} / \mathrm{mL}$ of insulin, and incubated for 2 $\mathrm{d}$, followed by culturing with DMEM containing $10 \%$ FBS and $1 \%$ penicillin/streptomycin for an additional $4 \mathrm{~d}$ $(8 \mathrm{~d})$, at the end of which more than $90 \%$ of the cells were mature adipocytes with accumulated fat droplets.

\section{Cell viability}

Cell viability was assessed by the MTT (3-(4,5-Dimethyl-2-thiazolyl)-2,5-diphenyl-2H-tetrazolium bromide) assay. The MTT assay was performed according to the modified method of Mosmann (1983). The 3T3-L1 preadipocytes were placed in 96-well microliter plates at a density of $16 \times 10^{4}$ cells/well. After $24 \mathrm{~h}$ incubation, the culture medium was replaced by $100 \mu \mathrm{L}$ of serial dilutions $(10,100,1000 \mathrm{mg} / \mathrm{mL})$ of the sample, and the cells were incubated for $24 \mathrm{~h}$. After incubation, $20 \mu \mathrm{L}$ of sterile filtered MTT solution $(5 \mathrm{mg} / \mathrm{mL}$ ) in PBS (PBS, $0.85 \%$ $\mathrm{NaCl}, 2.68 \mathrm{mM} \mathrm{KCl}, 10 \mathrm{mM} \mathrm{Na}_{2} \mathrm{HPO}_{4}$ and $1.76 \mathrm{mM}$
$\mathrm{KH}_{2} \mathrm{PO}_{4}$ were dissolved in distilled water, $\mathrm{pH}$ 7.4) was added to each well. Unreacted dye was removed after $4 \mathrm{~h}$ incubation. Insoluble formazan crystals were dissolved in $100 \mu \mathrm{L} /$ well of dimethyl sulfoxide (DMSO) and measured spectrophotometrically in an ELISA reader (BioTek, USA) at $550 \mathrm{~nm}$ (sample A). The non-treated cell was also dissolved in $100 \mu \mathrm{L} /$ well of DMSO and the absorbance was recorded at $550 \mathrm{~nm}$ (control A). The percent viability was expressed using the following formula:

$$
\text { Cell viability }(\%)=100-\left[\left(\frac{\text { control A-sample A }}{\text { control A }}\right) \times 100\right]
$$

\section{Sample preparation and treatment $L$. plantarum Q180}

L. plantarum Q180 was incubated at $37^{\circ} \mathrm{C}$ for $18 \mathrm{~h}$ in MRS broth. All of the purified strains were kept at $70^{\circ} \mathrm{C}$ until use. After culturing the L. plantarum Q180, all of the strains were harvested in a refrigerated centrifuge $\left(1,500 \mathrm{~g}\right.$ for $15 \mathrm{~min}$ at $\left.4^{\circ} \mathrm{C}\right)$ and washed three times with distilled water to remove any remaining MRS broth. The washed L. plantarum Q180 was freeze-dried and re-suspended in distilled water at a concentration of $10 \mathrm{mg} / \mathrm{mL}$ and homogenized for $50 \mathrm{sec}$ followed by $1 \mathrm{~min}$ of rest (repeated 3 times) using a sonicator. The 3T3-L1 cells were treated with $100 \mathrm{~g} / \mathrm{mL}$ of the sample. The concentration of the sample was determined according to the result of the MTT assay.

\section{Oil red $\mathrm{O}$ staining of 3T3-L1 adipocyte}

Intracellular lipid accumulation was measured using oil red O (Sigma, USA). Oil red O staining of 3T3-L1 cells was performed using a modified version of the method described by Ramirez-Zacarias et al. (1992). 3T3-L1 cells were washed with PBS twice, fixed with $10 \%$ formaldehyde/PBS at $4^{\circ} \mathrm{C}$ for $1 \mathrm{~h}$, and stained with filtered oil red O solution (stock solution: $3.5 \mathrm{mg} / \mathrm{mL}$ in isopropanol; working solution: $60 \%$ oil red O stock solution and $40 \%$ distilled water) at room temperature for $30 \mathrm{~min}$. The quantification of lipid accumulation was achieved by the oil red $\mathrm{O}$ obtained from stained cells with isopropyl alcohol and measured spectrophotometrically at $520 \mathrm{~nm}$. The material stained with oil red $\mathrm{O}$ was expressed on a per cell basis using the number of cells determined from similar plates. The percentage of the material stained with oil red $\mathrm{O}$ relative to the control wells containing the cell culture medium without compounds was calculated as $520 \mathrm{~nm}$ $(\mathrm{Q} 180) / 520 \mathrm{~nm}($ control $) \times 100$. 
Table 1. Independent variables and their levels in the 3-factor, 3-level central composite rotatable design optimizing the incubation condition of $L$. plantarum Q180

\begin{tabular}{ccccc}
\hline \hline \multirow{2}{*}{ Independent variables } & \multirow{2}{*}{ Symbol } & \multicolumn{3}{c}{ Level } \\
\cline { 3 - 5 } & & -1 & 0 & 1 \\
\hline Skim milk powder $(\%)$ & $\mathrm{X}_{1}$ & 9 & 10 & 11 \\
Incubation temp. $\left({ }^{\circ} \mathrm{C}\right)$ & $\mathrm{X}_{2}$ & 34 & 37 & 40 \\
Incubation time $(\mathrm{h})$ & $\mathrm{X}_{3}$ & 20 & 30.5 & 41 \\
\hline
\end{tabular}

\section{Anti-lipase activity}

The method of determining lipase activity proposed by Lee et al. (1993) was modified. Pancreatic lipase activity was measured using porcine pancreatic lipase (Sigma, USA). $0.1 \mathrm{mg} / \mathrm{mL}$ of a sample solution dissolved in water, $0.167 \mathrm{mM} p$-Nitrophenylpalmitate (PNP; Sigma, USA) solution and $0.061 \mathrm{M}(\mathrm{pH} 8.5)$ Tris- $\mathrm{HCl}$ buffer were mixed in the well of a plate, and $0.3 \mathrm{mg} / \mathrm{mL}$ of the lipase solution was then added to start the enzyme reaction. After incubation at $25^{\circ} \mathrm{C}$ for $10 \mathrm{~min}$, its absorbance was measured at $405 \mathrm{~nm}$.

\section{Experimental design}

To optimize the fermentative condition of $L$. plantarum Q180, concentration of skim milk powder $\left(\%, \mathrm{X}_{1}\right)$, incubation temperature $\left({ }^{\circ} \mathrm{C}, \mathrm{X}_{2}\right)$, and incubation time $\left(\mathrm{h}, \mathrm{X}_{3}\right)$ were used as the independent factors. In this design there are three experimental levels: $-1,0,1$. The range and center point values of the three independent factors were chosen after a series of preliminary single factor experi- ments (Table 1). $\mathrm{pH}\left(\mathrm{pH}, \mathrm{Y}_{1}\right)$, anti-lipase activity $\left(\%, \mathrm{Y}_{2}\right)$, and anti- adipogenetic activity $\left(\mathrm{pH}, \mathrm{Y}_{3}\right)$ were selected as the dependent factors.

\section{Response surface methodology}

The central composite design (CCD) described by Box and Wilson (1951) was adopted for the optimization of the anti-obesity activity of $L$. plantarum Q180. The CCD in the experimental design consisted of $2^{3}$ factorial points, six axial points $(\alpha=2)$, and three replicates of the central point (Table 2). Experimental runs were randomized in order to minimize the effects of unexpected variabilities in the observed responses.

\section{Analysis of the data}

The statistical analysis of the data and the multiple response optimizations were calculated by the desirability function of MINITAB statistical software (Version 13, Minitab Inc., USA). The statistical analysis was performed to fit the following quadratic polynomial equation:

$$
Y=\beta_{0}+\sum_{i=1}^{3} \beta_{i} X_{i}+\sum_{i=1}^{3} \beta_{i i} X_{i}^{2}+\sum_{i=1}^{2} \sum_{j=i+1}^{3} \beta_{i j} X_{i} X_{j}
$$

Where Y represents the dependent variables $(\mathrm{pH}$, antilipase activity and anti-adipogenetic activity), $\beta_{0}$ is constant, $\beta_{i}, \beta_{i i}, \beta_{i j}$ are regression coefficients, and $X i, X j$ are levels of the independent variables. Multiple response optimizations were performed to search for the condition

Table 2. Central composite design and responses of dependent variables for fermented milk with Lactobacillus plantarum Q180 to independent variables

\begin{tabular}{|c|c|c|c|c|c|c|}
\hline \multirow{2}{*}{ Run No. } & \multicolumn{3}{|c|}{ Coded levels of variables } & \multicolumn{3}{|c|}{ Responsee } \\
\hline & $\mathrm{X}_{1}$ & $\mathrm{X}_{2}$ & $\mathrm{X}_{3}$ & $\mathrm{Y}_{1}$ & $\mathrm{Y}_{2}$ & $\mathrm{Y}_{3}$ \\
\hline 1 & -1 & -1 & -1 & 5.56 & 22.92 & 19.17 \\
\hline 2 & 1 & -1 & -1 & 5.87 & 11.94 & -2.39 \\
\hline 3 & -1 & 1 & -1 & 4.70 & 46.49 & 13.73 \\
\hline 4 & 1 & 1 & -1 & 4.72 & 5.41 & 5.94 \\
\hline 5 & -1 & -1 & 1 & 5.38 & 55.40 & 10.29 \\
\hline 6 & 1 & -1 & 1 & 5.44 & 51.05 & -4.02 \\
\hline 7 & -1 & 1 & 1 & 4.14 & 67.44 & 12.28 \\
\hline 8 & 1 & 1 & 1 & 4.29 & 33.47 & 5.58 \\
\hline 9 & -1.68179 & 0 & 0 & 4.4. & 48.65 & 26.78 \\
\hline 10 & 1.68179 & 0 & 0 & 4.63 & 56.54 & -2.57 \\
\hline 11 & 0 & -1.68179 & 0 & 6.02 & 5.58 & 13.91 \\
\hline 12 & 0 & 1.68179 & 0 & 4.72 & 47.20 & 5.76 \\
\hline 13 & 0 & 0 & -1.68179 & 5.40 & 21.75 & 30.04 \\
\hline 14 & 0 & 0 & 1.68179 & 4.23 & 60.71 & 10.11 \\
\hline 15 & 0 & 0 & 0 & 4.55 & 56.60 & 18.44 \\
\hline 16 & 0 & 0 & 0 & 4.43 & 53.75 & 16.45 \\
\hline 17 & 0 & 0 & 0 & 4.40 & 56.54 & 15.00 \\
\hline
\end{tabular}

$\mathrm{X}_{1}$ : skim milk powder $(\%), \mathrm{X}_{2}$ : incubation temp. $\left({ }^{\circ} \mathrm{C}\right), \mathrm{X}_{3}$ : incubation time (h); $\mathrm{Y}_{1}: \mathrm{pH}, \mathrm{Y}_{2}$ : anti-lipase activity $(\%)$, $\mathrm{Y}_{3}$ : anti-adipogenetic activity (\%). 
(A)

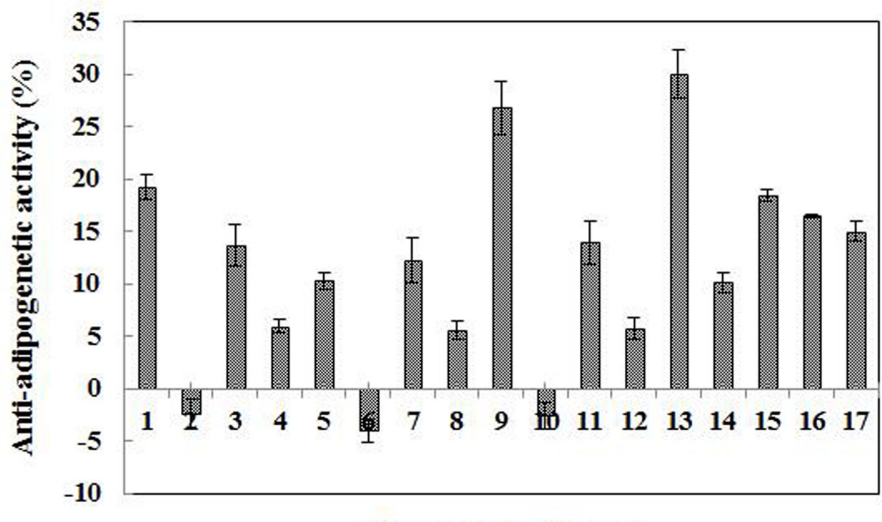

(B)

The number of cases

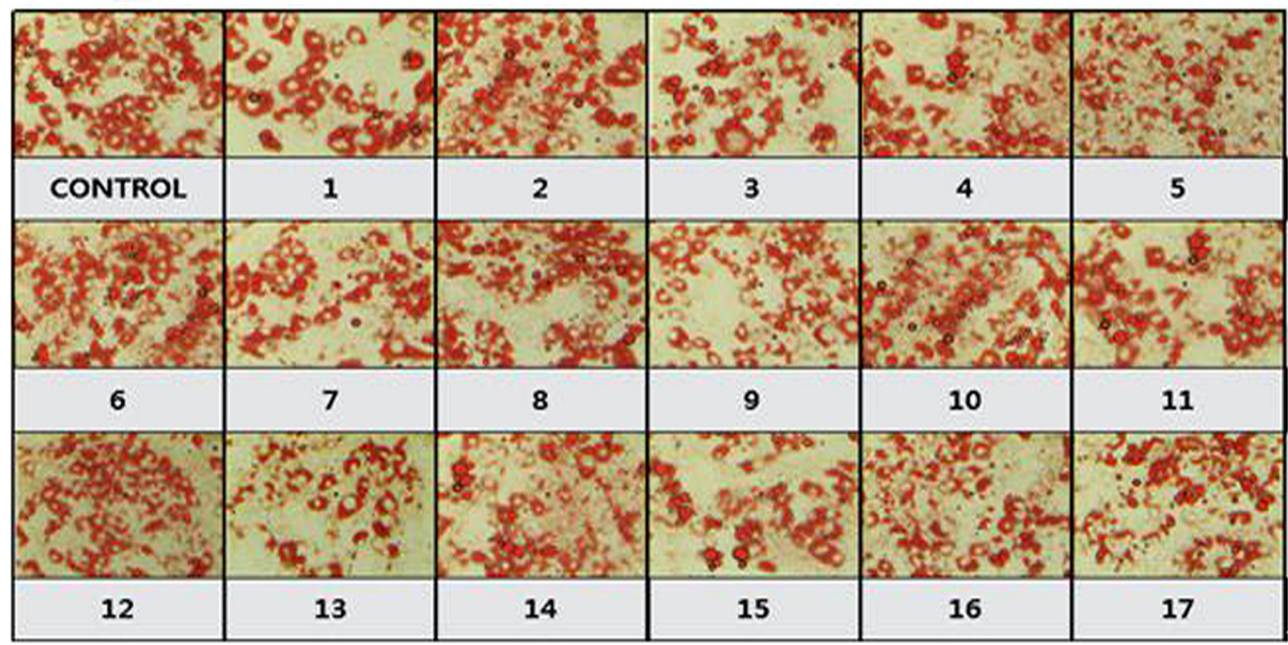

Fig. 1. The effects of $L$. plantarum Q180 on oil red $O$ stained in 3T3-L1 adipocyte. (A) Anti-adipogenetic activity. All values are the mean \pm standard deviation of three replicates. (B) Photograph of oil red O staining. Cells were stained with oil red O observed by using a microscope (original magnification $\times 200$ ).

that could simultaneously satisfy the three dependent variables $\left(\mathrm{Y}_{1}, \mathrm{Y}_{2}\right.$ and $\left.\mathrm{Y}_{3}\right)$. The response surface plots were developed using Maple software (Maple 7, Waterloo Maple Inc., Canada), and represented a function of two independent variables, while keeping the another independent variables at the optimal values.

\section{Results and Discussion}

\section{Diagnostic checking of the fitted models}

The $\mathrm{pH}$, anti-lipase activity, and anti-adipogenetic activity were measured by the seventeen fermentation conditions (Table 2 and Fig. 1). MINITAB statistical software was employed to fit the quadratic polynomial equation to the experimental data. All the coefficients of linear $\left(X_{1}\right.$, $\left.\mathrm{X}_{2}, \mathrm{X}_{3}\right)$, square $\left(\mathrm{X}_{11}, \mathrm{X}_{22}, \mathrm{X}_{33}\right)$ and interaction $\left(\mathrm{X}_{12}, \mathrm{X}_{13}\right.$, $\mathrm{X}_{23}$ ) were calculated with a $t$-statistic to determine their significance. The estimated coefficients of each model are presented in Table 3. As a result of the significance test, in the case of $Y_{1}(\mathrm{pH}), \mathrm{X}_{2}$ and $\mathrm{X}_{3}$ were found to be lower than the significance level ( $p$-value) of 0.05 in the firstorder term, and are thus statistically significant, and exercised great influence on the dependent variables. The cross-terms were not statistically significant, except for $\mathrm{X}_{2} \mathrm{X}_{2}$, and $\mathrm{X}_{3} \mathrm{X}_{3}$. In the case of $\mathrm{Y}_{2}$ (anti-lipase activity, $\%), X_{3}$ was significant and exercised a great influence on the dependent variables. It was shown that the crossterms were not statistically significant, except for $\mathrm{X}_{2} \mathrm{X}_{2}$. In the case of $Y_{3}$ (anti-adipogenetic activity, \%), $X_{1}$ showed significance and had a great influence on the dependent variables, and none of the cross-terms was statistically significant. The reaction equation obtained on the basis of the above results is shown in Table 4. A proper second-order polynomial expression model was obtained on the basis of the results of the response surface analysis. The coefficients of determination $\left(R^{2}\right)$ for $Y_{1}, Y_{2}$ and 
Table 3. Estimated effects and coefficients for $\mathrm{pH}$, anti-lipase activity and anti-adipogenetic activity (coded units) about Lactobacillus plantarum $\mathbf{Q 1 8 0}$

\begin{tabular}{|c|c|c|c|c|c|c|}
\hline \multirow{2}{*}{$\begin{array}{l}\text { Variable and } \\
\text { interaction }\end{array}$} & \multicolumn{2}{|c|}{$\mathrm{Y}_{1}$} & \multicolumn{2}{|c|}{$\overline{Y_{2}}$} & \multicolumn{2}{|c|}{$\mathrm{Y}_{3}$} \\
\hline & Coeffficient & $p$ value & Coeffficient & $p$ value & Coeffficient & $p$ value \\
\hline Intercept & 4.45481 & 0.000 & 7.807 & 0.000 & 4.684 & 0.002 \\
\hline $\mathrm{X}_{1}$ & 0.06417 & 0.216 & -1.682 & 0.136 & -4.276 & 0.004 \\
\hline $\mathrm{X}_{2}$ & -0.48227 & 0.000 & 1.778 & 0.119 & 0.034 & 0.974 \\
\hline$X_{3}$ & -0.26124 & 0.001 & 4.061 & 0.005 & -1.965 & 0.090 \\
\hline $\mathrm{X}_{1} \mathrm{X}_{1}$ & 0.04262 & 0.439 & -0.433 & 0.678 & -1.593 & 0.155 \\
\hline $\mathrm{X}_{2} \mathrm{X}_{2}$ & 0.33961 & 0.000 & -2.941 & 0.022 & -2.019 & 0.083 \\
\hline $\mathrm{X}_{3} \mathrm{X}_{3}$ & 0.14338 & 0.028 & -1.521 & 0.172 & -0.093 & 0.928 \\
\hline$X_{1} X_{2}$ & -0.02500 & 0.679 & -1.703 & 0.132 & 1.198 & 0.270 \\
\hline $\mathrm{X}_{1} \mathrm{X}_{3}$ & -0.01500 & 0.815 & 0.392 & 0.707 & 0.467 & 0.655 \\
\hline $\mathrm{X}_{2} \mathrm{X}_{3}$ & -0.04750 & 0.466 & -0.644 & 0.540 & 0.487 & 0.641 \\
\hline
\end{tabular}

$\mathrm{X}_{1}$ : skim milk powder (\%), $\mathrm{X}_{2}$ : incubation temp. $\left({ }^{\circ} \mathrm{C}\right), \mathrm{X}_{3}$ : incubation time (h); $\mathrm{Y}_{1}: \mathrm{pH}, \mathrm{Y}_{2}$ : anti-lipase activity (\%), $\mathrm{Y}_{3}$ : anti-adipogenetic activity (\%).

Table 4. Response surface model for making condition

\begin{tabular}{|c|c|c|c|}
\hline$\overline{\text { Responses }}$ & Quadratic polynomial model & $\overline{\mathrm{R}^{2}}$ & $\overline{p \text {-value }}$ \\
\hline $\mathrm{Y}_{1}$ & $\begin{array}{l}\mathrm{Y}_{1}=4.45481+0.06417 \mathrm{X}_{1}-0.48227 \mathrm{X}_{2}-0.26124 \mathrm{X}_{3}+0.04262 \mathrm{X}_{1} \mathrm{X}_{1}+0.33961 \mathrm{X}_{2} \mathrm{X}_{2}+ \\
0.14338 \mathrm{X}_{3} \mathrm{X}_{3}-0.02500 \mathrm{X}_{1} \mathrm{X}_{2}-0.01500 \mathrm{X}_{1} \mathrm{X}_{3}-0.04750 \mathrm{X}_{2} \mathrm{X}_{3}\end{array}$ & 0.963 & 0.000 \\
\hline $\mathrm{Y}_{2}$ & $\begin{array}{l}Y_{2}=55.784-5.646 X_{1}+5.967 X_{2}+13.628 X_{3}-1.599 X_{1} X_{1}-10.864 X_{2} X_{2}-5.617 X_{3} X_{3}- \\
7.466 X_{1} X_{2}+1.717 X_{1} X_{3}-2.822 X_{2} X_{3}\end{array}$ & 0.835 & 0.000 \\
\hline $\mathrm{Y}_{3}$ & $\begin{array}{l}Y_{3}=17.0408-7.3044 X_{1}+0.0573 X_{2}-3.3572 X_{3}-2.9947 X_{1} X_{1}-3.7956 X_{2} X_{2}- \\
0.1755 X_{3} X_{3}+2.6731 X_{1} X_{2}+1.0420 X_{1} X_{3}+1.0874 X_{2} X_{3}\end{array}$ & 0.810 & 0.002 \\
\hline
\end{tabular}

$\mathrm{X}_{1}$ : skim milk powder (\%), $\mathrm{X}_{2}$ : incubation temp. $\left({ }^{\circ} \mathrm{C}\right), \mathrm{X}_{3}$ : incubation time $(\mathrm{h}) ; \mathrm{Y}_{1}: \mathrm{pH}, \mathrm{Y}_{2}$ : anti-lipase activity (\%), $\mathrm{Y}_{3}$ : anti-adipogenetic activity (\%).

Table 5. Analysis of varience for pH, GABA concentrations (coded units) about Lactobacillus plantarum K154

\begin{tabular}{|c|c|c|c|c|c|c|}
\hline & Source of variation & $\overline{\mathrm{DF}}$ & $\overline{\mathrm{SS}}$ & $\overline{\mathrm{MS}}$ & F-value & $p$-value \\
\hline \multirow{7}{*}{$\mathrm{Y}_{1}$} & Main effects & 9 & 5.57201 & 0.61911 & 20.39 & 0.000 \\
\hline & Linear & 3 & 4.16466 & 1.38822 & 45.72 & 0.000 \\
\hline & Square & 3 & 1.38249 & 0.46083 & 15.18 & 0.002 \\
\hline & 2-way interactions & 3 & 0.02485 & 0.00828 & 0.27 & 0.843 \\
\hline & Residual error & 7 & 0.21254 & 0.03036 & & \\
\hline & Lack of fit & 5 & 0.19994 & 0.03999 & 6.35 & 0.042 \\
\hline & Total & 16 & 5.78455 & & & \\
\hline \multirow{7}{*}{$\mathrm{Y}_{2}$} & Main effects & 9 & 5454.00 & 606.00 & 3.94 & 0.042 \\
\hline & Linear & 3 & 3457.83 & 1152.62 & 7.50 & 0.014 \\
\hline & Square & 3 & 1462.97 & 487.66 & 3.17 & 0.094 \\
\hline & 2-way interactions & 3 & 533.17 & 177.72 & 1.16 & 0.392 \\
\hline & Residual error & 7 & 1076.48 & 153.78 & & \\
\hline & Lack of fit & 5 & 1071.19 & 214.24 & 280.98 & 0.012 \\
\hline & Total & 16 & 6530.48 & & & \\
\hline \multirow{6}{*}{$\mathrm{Y}_{3}$} & Main effects & 9 & 1188.26 & 132.029 & 3.31 & 0.064 \\
\hline & Linear & 3 & 882.63 & 294.210 & 7.38 & 0.014 \\
\hline & Square & 3 & 230.32 & 76.774 & 1.93 & 0.214 \\
\hline & 2-way interactions & 3 & 75.31 & 25.103 & 0.63 & 0.619 \\
\hline & Residual error & 7 & 279.01 & 39.859 & & \\
\hline & Lack of fit & 5 & 273.03 & 54.607 & 18.27 & 0.023 \\
\hline
\end{tabular}

DF, Degrees of freedom; SS, sum of squares; MS, Mean square (MS=SS/DF).

$\mathrm{Y}_{1}: \mathrm{pH}, \mathrm{Y}_{2}$ : anti-lipase activity (\%), $\mathrm{Y}_{3}$ : anti-adipogenetic activity (\%).

$\mathrm{Y}_{3}$ were $0.963,0.935$ and 0.810 , respectively, which indicates that the model is suitable to represent the real relationships among the selected reaction parameters. The values of $\mathrm{R}_{2}$ for all models were extremely high for the response surface and significant at $p=0.00$. The reason why the values obtained for $\mathrm{R}^{2}$ are quite high is that the 
experimental design was based on an adequately performed preliminary test.

\section{Analysis of variance}

The statistical significance of the quadratic polynomial model equation was evaluated by conducting an analysis of variance (ANOVA). Table 5 shows the ANOVA for the models that explain the response of the three dependent variables, $\mathrm{Y}_{1}(\mathrm{pH}), \mathrm{Y}_{2}$ (anti-lipase activity) and $\mathrm{Y}_{3}$ (antiadipogenetic activity). The square terms and 2-way interaction terms for the dependent variables $\left(\mathrm{Y}_{1}, \mathrm{Y}_{2}\right.$ and $\left.\mathrm{Y}_{3}\right)$ were not significant, except for the square terms of $Y_{1}$ $\left(\mathrm{Y}_{1}: p=0.002\right.$ and $p=0.843, \mathrm{Y}_{2}: p=0.094$ and $p=0.392, \mathrm{Y}_{3}$ : $p=0.214$ and $p=0.619$, respectively) at the $95 \%$ probability level $(p<0.05)$, whereas the linear term and total regression model were significant at the $95 \%$ probability level, except for the total regression model of $\mathrm{Y}_{3}$. In this design, the data were highly influenced by the linear term. As regards the results of the lack-of-fit test, which indicates the fitness of the model, all the dependent variables were significant at the $95 \%$ probability level.

\section{Conditions for optimum responses}

In order to find the condition for optimum responses, the desirability function of the MINITAB statistical software was used. Optimal conditions included the coded and un-coded values of each dependent variable $\left(\mathrm{Y}_{1}, \mathrm{Y}_{2}\right.$ and $\mathrm{Y}_{3}$ ), which are shown in Table 6. The results of performing the optimization of fermented milk each under conditions showing the highest anti-lipase activity and antiadipogenetic activity and targeting the $\mathrm{pH} 4.4$ showed that the critical values were different in all data. However, the result of the optimization satisfying both conditions at the same time showed that the coded values of the independent variables were the concentration of skim milk powder, $X_{1}=-0.4572$; incubation temperature, $X_{2}=0.0548$; and incubation time, $X_{3}=-0.2134$; respectively. The actual values of the independent variables against the coded values were $X_{1}=9.5 \%, X_{2}=37^{\circ} \mathrm{C}$ and $X_{3}=28 \mathrm{~h}$. The predicted values of multiple response optimal conditions were $\mathrm{Y}_{1}=$ $\mathrm{pH} 4.47, \mathrm{Y}_{2}=55.55 \%$ and $\mathrm{Y}_{3}=20.48 \%$.

\section{Response surface plots and the effect of factors}

Fig. 2 shows the estimated response function and the effect of the independent variables $\left(\mathrm{X}_{1}, \mathrm{X}_{2}\right.$ and $\left.\mathrm{X}_{3}\right)$ and dependent variables $\left(\mathrm{Y}_{1}, \mathrm{Y}_{2}\right.$ and $\left.\mathrm{Y}_{3}\right)$. The response surface plot presents the interrelationship between two independent variables and one dependent variable, while keeping another independent variable at the optimal values. It is considered that two factors, i.e. incubation temperature and incubation time, affect anti-lipase activity $\left(\mathrm{Y}_{2}\right)$ among the fermentation conditions for fermented milk with an excellent anti-obesity effect, and that all three independent variables affect the $\mathrm{pH}\left(\mathrm{Y}_{1}\right)$ and anti-adipogenetic activity $\left(\mathrm{Y}_{3}\right)$.

\section{Verification of predicted values}

Verification experiments were conducted under optimal conditions (concentration of skim milk powder $=9.5 \%$, incubation temperature $=37^{\circ} \mathrm{C}$, and incubation time $=28$ h) to compare the predicted values and the actual values of the dependent variables (Table 7). The actual values, which were repeated three times, were $\mathrm{pH}=4.50$, antilipase activity $=52.86 \%$, and anti-adipogenetic activity $=$ $19.25 \%$ against the predicted values of $\mathrm{pH}=4.47$, antilipase activity $=55.55 \%$, and anti-adipogenetic activity $=$

Table 6. Optimal conditions of $\mathrm{pH}$ and GABA concentrations

\begin{tabular}{|c|c|c|c|c|c|}
\hline \multirow{2}{*}{ Dependent } & \multirow{2}{*}{$\begin{array}{c}\text { Independent } \\
\text { variables }\end{array}$} & \multicolumn{2}{|c|}{ Critical value } & \multirow{2}{*}{ Predicted value } & \multirow{2}{*}{ Stationary point } \\
\hline & & Coded & Uncoded & & \\
\hline \multirow{3}{*}{$Y_{1}$} & $\mathrm{X}_{1}$ & 0 & 10 & 4.4 & Target \\
\hline & $X_{2}$ & 0 & 37 & & \\
\hline & $\mathrm{X}_{3}$ & 0.2419 & 33.0399 & & \\
\hline \multirow{3}{*}{$\mathrm{Y}_{2}$} & $\mathrm{X}_{1}$ & -1.6818 & 8.3182 & 67.42 & Maximum \\
\hline & $\mathrm{X}_{2}$ & 1.4017 & 41.2051 & & \\
\hline & $X_{3}$ & 0.6063 & 36.8661 & & \\
\hline \multirow{3}{*}{$\mathrm{Y}_{3}$} & $\mathrm{X}_{1}$ & -1.4677 & 8.4677 & 31 & Maximum \\
\hline & $\mathrm{X}_{2}$ & -0.5395 & 65.3815 & & \\
\hline & $X_{3}$ & -1.6818 & 12.8412 & & \\
\hline \multirow{3}{*}{$\begin{array}{l}\text { Multiple response } \\
\text { optimization }\end{array}$} & $\mathrm{X}_{1}$ & -0.4572 & 9.5428 & & \\
\hline & $\mathrm{X}_{2}$ & 0.0548 & 37.1644 & & \\
\hline & $\mathrm{X}_{3}$ & -0.2134 & 28.2593 & & \\
\hline
\end{tabular}

$\mathrm{X}_{1}$ : skim milk powder (\%), $\mathrm{X}_{2}$ : incubation temp. $\left({ }^{\circ} \mathrm{C}\right), \mathrm{X}_{3}$ : incubation time $(\mathrm{h}) ; \mathrm{Y}_{1}: \mathrm{pH}, \mathrm{Y}_{2}$ : anti-lipase activity (\%), $\mathrm{Y}_{3}$ : anti-adipogenetic activity (\%). 

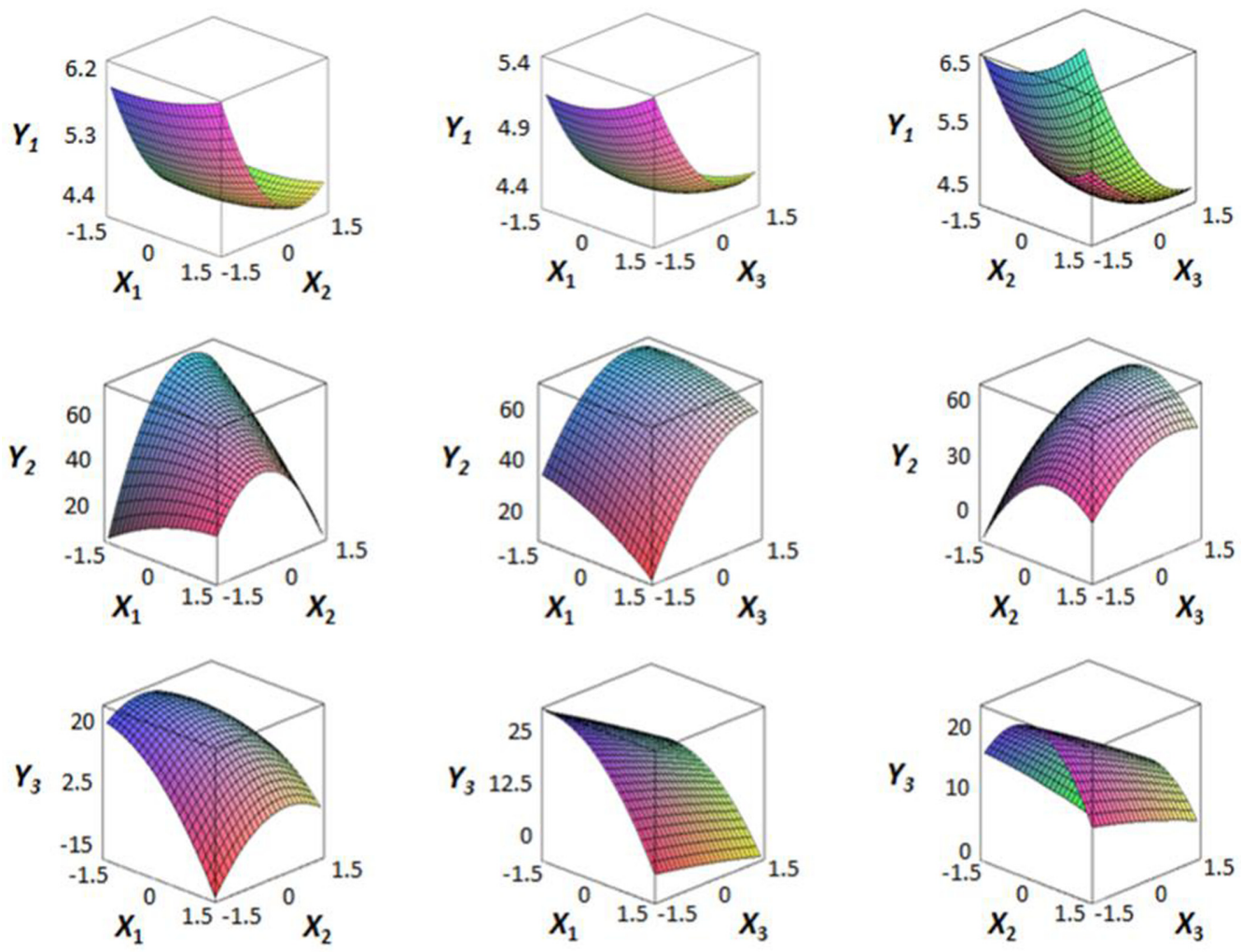

Fig. 2. Response surface plots for the effect of independent variables on dependent (pH, anti-lipase activity, and anti-adipogenetic activity). $\mathrm{X}_{1}$ : skim milk powder $(\%), \mathrm{X}_{2}$ : incubation temp. $\left({ }^{\circ} \mathrm{C}\right), \mathrm{X}_{3}$ : incubation time $(\mathrm{h}) ; \mathrm{Y}_{1}: \mathrm{pH}, \mathrm{Y}_{2}$ : anti-lipase activity $(\%), \mathrm{Y}_{3}$ : anti-adipogenetic activity (\%).

Table 7. Predicted results of verification under optimized conditions

\begin{tabular}{ccc}
\hline Dependent & Predicted value & Experimental value \\
\hline $\mathrm{Y}_{1}(\mathrm{pH})$ & 4.47 & $4.50 \pm 0.03$ \\
$\mathrm{Y}_{2}$ (lipase, \%) & 55.55 & $52.86 \pm 0.86$ \\
$\mathrm{Y}_{3}$ (adiposite, \%) & 20.48 & $19.25 \pm 0.53$ \\
\hline
\end{tabular}

All values are mean \pm standard deviation of three replicates.

$20.48 \%$. Both the actual values and the predicted values almost coincided with each other. According to Park et al. (2011), the lipid content in differentiated cells decreased by $11 \pm 3.6 \%$ when treated with $0.01 \%$ of $L$. plantarum KY1032, a strain isolated from kimchi. Therefore, the estimated response surface model has an excellent antiobesity effect and can be adapted to optimize the production of functional fermented milk with an anti-obesity effect obtained from L. plantarum Q180.

\section{Conclusion}

We investigated the optimum condition for producing functional fermented milk with an anti-obesity effect by using L. plantarum Q180. We used a 3-factor, 3-level
CCD combined with RSM. Concentrations of skim milk powder $\left(\%, \mathrm{X}_{1}\right)$, incubation temperature $\left({ }^{\circ} \mathrm{C}, \mathrm{X}_{2}\right)$, and incubation time ( $\mathrm{h}, \mathrm{X}_{3}$ ) were used as the independent factors, while $\mathrm{pH}\left(\mathrm{pH}, \mathrm{Y}_{1}\right)$, anti-lipase activity $\left(\%, \mathrm{Y}_{2}\right)$ and anti-adipogenetic activity $\left(\%, \mathrm{Y}_{3}\right)$ were used as the dependent factors. The optimal conditions of fermented milk for the highest anti-lipase and anti-adipogenetic activity with $\mathrm{pH} 4.4$ were the $9.5 \%$ of skim milk powder, $37^{\circ} \mathrm{C}$ of incubation temperature, $28 \mathrm{~h}$ of incubation time. In the fermentation condition, the predicted values of $\mathrm{pH}$, anti-lipase activity and anti-adipogenetic activity were 4.47, 55.55, and $20.48 \%$, respectively. However, the actual values of $\mathrm{pH}$, anti-lipase activity and anti-adipogenetic activity were $4.50,52.86$, and $19.25 \%$, respectively. These results demonstrate that $9.5 \%$ of skim milk powder and incubation at $37^{\circ} \mathrm{C}$ for $28 \mathrm{~h}$ were the optimum conditions for producing functional fermented milk with an anti-obesity effect.

\section{Acknowledgements}

The research was supported by the High Value-added Food Technology Development Program, Ministry of 
Agriculture, Food and Rural Affairs.

\section{References}

1. Bezerra, M. A., Santelli, R. E., Oliveira, E. P., Villar, L. S., and Escaleira, L. A. (2008) Response surgace methodology (RSM) as a tool for optimization in analytical chemistry. Talanta 76, 965-977.

2. Box, G. E. P., Hunter, W. G., and Hunter, J. S. (1978) Statistics for experimenters. John Wiley and Sons, New York, 341418.

3. Box, G. E. P. and Wilson, K. B. (1951) On the experimental attainment of optimum condition. J. Roy. Statist. Soc. Ser. B. 13, 1-38.

4. Choi, S. S., Kim, Y., Han, K. S., You, S., Oh, S., and Kim, S. H. (2006) Effects of Lactobacillus strains on cancer cell proliferation and oxidative stress in vitro. Lett. Appl. Microbiol. 42, 452-458.

5. Hemati, N., Ross, S. E., Erickson, R. L, Groblewski, G. E., and MacDuygald, O. A. (1997) Signaling pathways through which insulin regulates CCAAT/enhancer binding protein- $\alpha$ $(\mathrm{C} / \mathrm{EBP}-\alpha)$ phosphorylation and gene expression in 3T3-L1 adipocytes. Forrelation with CLUT4 gene expression. J. Biol. Chem. 272, 25913-25919.

6. Kadooka, Y., Sato, M., Imaizumi, K., Ogawa, A., Ikuyama, K., Akai, Y., Okano, M., Kagoshima, M., and Tsuchida, T. (2010) Regulation of abdominal adiposity by probiotics ( Lactobacillus gasseri SBT2055) in adults with obese tendencies in a randomized controlled trial. Eur. J. Clin. Nutr. 64, 636643.

7. Karahan, A. G., Kilic, G. B., Kart, A., Aloglu, H. S., Oner, Z., Aydemir, S., Erkus, O., and Harsa, S. (2010) Genotypic identification or some lactic acid bacteria by amplified fragment length polymorphism analysis and investigation of their potential usage as starter culture combinations in Beyaz cheese manufacture. J. Dairy Sci. 93, 1-11.

8. Komatsuzaki, N., Shima, J., Kawamoto, S., Momose, H., and Kimura, T. (2005) Production of $\gamma$-aminobutyric acid (GABA) by Lactobacillus paracasei isolated from traditional fermen- ted foods. Food Microbiol. 22, 497-504.

9. Lee, Y. P., Chung G. H., and Rhee, J. S. (1993) Purification and characterization of Pseudomonas fluorescens SIK W1 lipase expressed in Escherichia coli. Biochim. Biophys. Acta. 1169, 156-164.

10. Leroy, F. and Vuyst, L. D. (2004) Lactic acid bacteria as functional starter cultures for the food fermentation industry. Trends Food Sci. Technol. 15, 17-78.

11. Mosmann T. (1983) Rapid colorimetric assay for cellular growth and survival: Application to proliferation and cytotoxicity assays. J. Immunol. Methods 62, 55-63.

12. Park, D. Y., Ahn, Y. T., Huh, C. S., Jeon, S. M., and Choi, M. S. (2011) The inhibitory effect of Lactobacillus plantarum KY1032 cell extract on the adipogenesis of 3T3-L1 cells. $J$. Med. Food. 10, 670-675.

13. Park, S. Y., Cho, S. A., Kim, S. H., and Lim, S. D. (2014) Physiological characteristics and anti-obesity effect of Lactobacillus plantarum Q180 isolated from feces. Korean J. Food Sci. An. 34, 645-653.

14. Ramirez-Zacarias, J. L., Castro-Munozledo, F., and Kuri-Harcuch, W. (1992) Quantitation of adipose conversion and triglycerides by staining intracytoplasmic lipids with Oil red O. Histochem. 97, 493-497.

15. Salminen, M. K., Tynkkynen, S., Rautelin, H., Saxelin, M., Vaara, M., Ruutu, P., Sarna, S., Valtonen, V., and Jarvinen, A. (2002) Lactobacillus bacteremia during a rapid increase in probiotic use of Lactobacillus rhamnosus GG in Finland. Clin. Infect. Dis. 35, 1155-1160.

16. Takemura, N., Okubo, T., and Sonoyama, K. (2010) Lactobacillus plantarum strain No. 14 reduces adipocyte size in mice fed high-fat diet. Exp. Biol. Med. 235, 849-856.

17. Tanida, M., Shen, J., Maeda, K., Horii, Y., Yamano, T., Fukushima, Y., and Nagai, K. (2008) High-fat diet-induced obesity is attenuated by probiotic strain Lactobacillus paracasei ST11 (NCC2461) in rats. Obes. Res. Clin. Pract. 2, 159-169.

18. Yanovski, S. Z. and Yanovski, J. A. (2002) Obesity. N. Engl. J. Med. 346, 591-602.

(Received 2014.9.22/Revised 2014.11.5/Accepted 2014.11.7) 